ENTREPRENEURSHIP AND SUSTAINABILITY ISSUES

ISSN 2345-0282 (online) http://jssidoi.org/jesi/

2020 Volume 7 Number 3 (March)

http://doi.org/10.9770/jesi.2020.7.3(42)

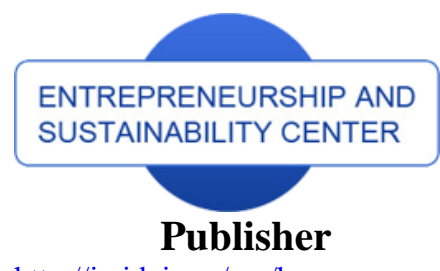

http://jssidoi.org/esc/home
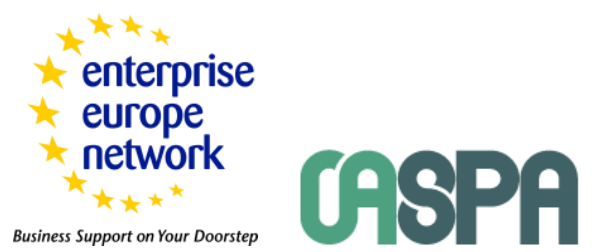

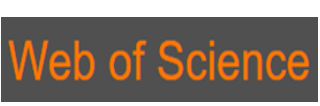

Clarivate
Analytics

\title{
HOW THE NEXUS AMONG THE FREE TRADE, INSTITUTIONAL QUALITY AND ECONOMIC GROWTH AFFECT THE TRADE FROM ASEAN COUNTRIES
}

\author{
Paitoon Chetthamrongchai ${ }^{1}$, Kittisak Jermsittiparsert ${ }^{2}$, Sakapas Saengchai ${ }^{3 *}$ \\ ${ }^{1}$ Faculty of Business Administration, Kasetsart University, Bangkok, Thailand \\ ${ }^{2}$ Department for Management of Science and Technology Development, Ton Duc Thang University, Ho Chi Minh City, \\ Vietnam \\ ${ }^{2}$ Faculty of Social Sciences and Humanities, Ton Duc Thang University, Ho Chi Minh City, Vietnam \\ ${ }^{3}$ Faculty of Humanities and Social Science, Suan Sunandha Rajabhat University, Bangkok, Thailand \\ E-mails: ${ }^{1}$ fbusptc@ku.ac.th $;{ }^{2}$ kittisak.jermsittiparsert@tdtu.edu.vn
}

Received 15 July 2019; accepted 12 January 2019; published 30 March 2020

\begin{abstract}
The main purpose of the study is to answer the research question that How the nexus among the free trade, institutional quality and economic growth effect the trade from ASEAN countries. The exports become uncompetitive because of such hidden tax and high production costs in ASEAN. It can be said that importer/importers can achieve competitive advantage by being involve in corrupt activities as compared to others who are not willing to give bribes. The trade can be enhanced or hindered through corruption based on the willingness of firms in the exporting countries to offer bribes at a competitive level. Precisely, the focus of the discussion is on the channels through which global trade can be influenced. This shows that the main influence of corruption, which is an institutional quality on the global trade, is an issue to be empirically investigated. Considering this notion, the previous knowledge has been extended by including some other variables of institutional quality such as good governance, instability of governance and corruption by keeping the focus on flow of trade in ASEAN. Moreover, the data is allowed to decide whether the variables of institutional quality i.e. instability of government, corruption and good governance influence the trade across the border in a positive or negative way in the ASEAN countries. The findings of the study have provided support to the hypothesized results.
\end{abstract}

Keywords: ASEAN; Trade; Economic growth; Institutional quality

Reference to this paper should be made as follows: Chetthamrongchai, P., Kittisak Jermsittiparsert, K., Saengchai, S. 2020. How the nexus among the free trade, institutional quality and economic growth ffect the trade from ASEAN countries. Entrepreneurship and Sustainability Issues, 7(3), 2079-2094. https://doi.org/10.9770/jesi.2020.7.3(42)

JEL Classifications: O15, N60

\section{Background}

International economies have undergone a series of significant developments during the last few decades, including the formation and implementation of bilateral and regional trade agreements. A wave of trade liberalization is quickly reshaping the nature of cross border transactions. With the re-emergence of neo-liberal philosophy in the 1980s espousing the removal of all forms of trade restrictions, most developing countries did an abrupt U-turn in their major policy thrusts to embrace neo-liberal economic development orthodoxy. In the early 
ENTREPRENEURSHIP AND SUSTAINABILITY ISSUES

ISSN 2345-0282 (online) http://jssidoi.org/jesi/

2020 Volume 7 Number 3 (March)

http://doi.org/10.9770/jesi.2020.7.3(42)

part of 1990s, the number of regional trade agreements increased and continued to grow. According to the World Trade Organization (WTO), regional trade agreements (RTAs) can be defined as reciprocal trade agreements among two or more partners and as of June 2014 about 585 notifications of Regional Trade Agreements (RTA) were received while 379 were in force (WTO, 2014).

This explosion of trade agreements was fuelled by several developments. The United States created the bilateral Free Trade Agreement (FTA) with Canada in 1987 and the North American Free Trade Agreement that included, Canada, Mexico and the United States in 1994, and the establishment of the European Union in 1993 helped fan the flames of free trade. The General Agreement on Tariffs and Trade, which began in 1948, morphed into the World Trade Organization in 1995, and the number of RTAs that announced their intentions to joint increased rapidly (WTO, 2014) showing a significant increase from the mere forty RTAs that existed in 1990 (Lu, 2017). As these trade agreements expanded, they created what has been called a "spaghetti bowle of RTAs with the provisions of many RTAs cutting across each other (Murphy \& McLarney, 2018).In general, five types of integration exist: Common Market (CM), Custom Union (CU),Free Trade Area (FTA), Preferential Trade Agreements (PTA), and an Economic andMonetary Union (EMU). The desire to achieve economic growth across the continent has prompted many Asian countries to create regional cooperation. See Figure 1.

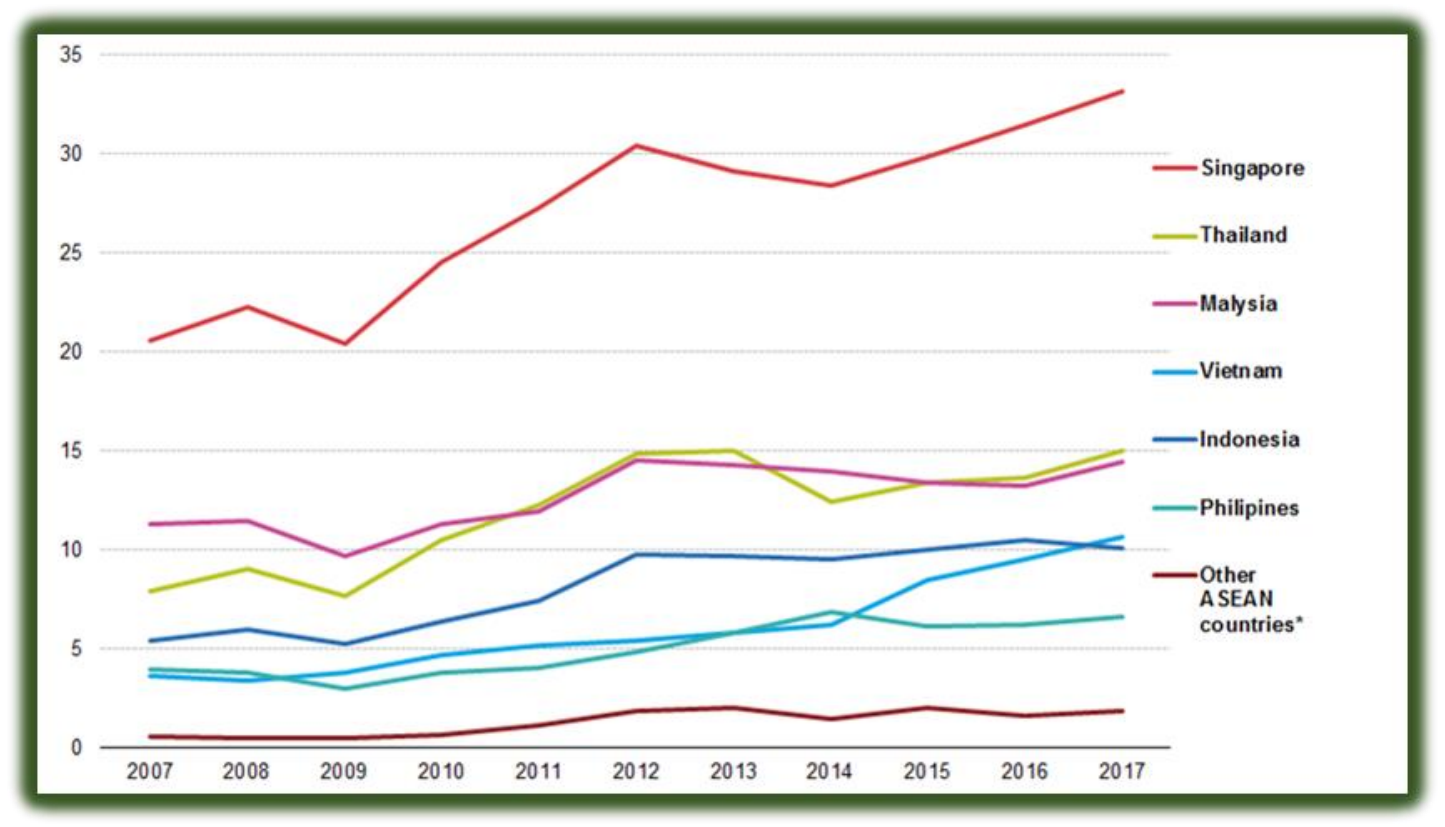

Figure 1. Export of ASEAN countries

Source World Bank

In literature, the area of trade nexus and institutional quality reflects that corruption is a variable of institutional quality, which hinders global trade. There might be a possibility that corruption is affected through global trade, but the relation runs from trade to corruption casually. The flow of trade can become low because of trade barriers, which promotes black market and increase in corruption. The traditional research studies on corruption have elaborated three different ways such as the channel of efficiency, the price mark-up, and the awarding of contract. The economic progress is influenced through the change in efficiency by the corruption under the channel of efficiency. The growth and economic efficiency can be enhanced through the speed money when the pervasive and cumbersome regulations in the economy are exogenous. In a study, it was argued by researchers that the government employees consider bribes as a piece rate. It was also shown that individual bypass the delays 


\section{ENTREPRENEURSHIP AND SUSTAINABILITY ISSUES}

ISSN 2345-0282 (online) http://jssidoi.org/jesi/

2020 Volume 7 Number 3 (March)

http://doi.org/10.9770/jesi.2020.7.3(42)

in bureaucratic because of bribes. This sort of corruption can result in growth of global trade. It was indicated by Kölbl (2015) that the welfare can be improved by corruption when the resource transferring enticements replace the queue up costs.

Inefficiency can also be resulted through corruption. It was indicated by Boianovsky (2019a) that the corrupt government officials can make delay in the administrative works for getting more bribes rather than enhancing the speed of procedure. It was discovered by Sartor and Beamish (2018) that when more bribes are paid by firms, this results in more time for management including negotiation of bureaucratic regulations. This can include higher capital cost. The trade can be reduced or improved under the cost channel transaction or price markup. However, this is based on the theft involvement (Hussain et al., 2019). It was argued by Della Porta (2017) that when theft is involved in corruption, this is referred as collusive corruption. Bribes can be levied by the government officials, which can be lower than the official rate of tax. The shipment arrived in an economy may have low cost of transaction this reduces the mark up price that enhances trade. The government becomes the loser and the exporters/importers taking bribe becomes the winner.

When theft is involved in corruption, extra charges are added by the agent in addition to the official duty. This refers to some hidden tax, which increases the transaction cost and lowers international trade. This channel was discussed by Thompson (2017) in their predation model. It was argued by the researchers that corrupt officials could attack the shipments. In this regard, the shipment should be defended by taking customary measures. In other case, it can be easily caught by the corrupt officials. Defensive measures are taken by the exporters/importers under these circumstances and attack can be made by the corrupt officials. Shipment becomes a game of probability in this situation. A particular shipment can be lost, which can decide about the transaction costs and price markup. The chance of a shipment departure from the initial point and reaching the final point is involved in this condition. It can be assumed that some value proportions or part of shipment can be lost. The level of corruption highlights that there is increased loss chance that ultimately result in enhanced price markups. The hidden tax on the international trade is equivalent to the high markup price. This reduces the level of trade between two countries.

\section{Literature review}

\subsection{Influence of Trade on different Regional Trade Integrations}

The bilateral trade increases with the decrease in trade barrier in the SAARC region (South Association for Regional Cooperation). Moreover, it was discovered by Doan and Xing (2018) that CMEA and EEC regional trade was enhanced in the duration 1960-1994. Mediterranean countries were examined by Andersson and Sundqvist (2018) with EU to find whether the export of these countries to EU increased when the free trade area deal was sealed by Barcelona conference of 1995 between the two regions. It was analyzed that the bilateral trade was increased by 140 percent above the forecast between the two countries, which was discovered in the gains of regional group of ASEANs and its members. At the same time, it was discovered by Karemera, Whitesides, and Smalls (2017) that trade was induced between the groups because of the convincing outcome for EFTA and EEC for the years 1965-1976. It was analyzed that the trade of SAARC with the non-member countries can increase in general. During the years of 1960-1994, more trade was done by the member countries of EEC with the countries outside the region. It was discovered that trade of ASEAN countries with non-ASEAM has increased. The economic benefit of integration of region was analyzed by Öncel and Lubis (2017) on Vietnam through use of CGE model (computable general equilibrium). The research included the countries i.e. Indonesia, Japan, China, Malaysia, Philippines, and some East Asian economies. The welfare level and distribution of income for Vietnam increase with the regional integration. The income and household consumption increased that benefited the poor people. The access to bigger markets was facilitated through removal of tariffs between the trading members in the region, which increased the level of exports. 


\section{ENTREPRENEURSHIP AND SUSTAINABILITY ISSUES}

ISSN 2345-0282 (online) http://jssidoi.org/jesi/

2020 Volume 7 Number 3 (March)

http://doi.org/10.9770/jesi.2020.7.3(42)

An investigation was carried out on the outcomes of RTAs for EU for improving economic growth between the member countries. It was discovered by researcher that there is a positive relation between the growth and trade. There is considerable difference between the convergence of knowledge and external trade. A great influence of knowledge spill over is created on the growth. There is a relation of knowledge transfer between growth and TFP. Moreover, the advantages and disadvantages of integration agreement for regional trade in the EAC (East African Community) were examined by Nguyen and Kim (2019). The benefits of integration of trade in the CARs (Central Asian Republics) were investigated through use of CGE (computable general equilibrium) and it was found that this agreement was a considered part of integration. Moreover, it was found that there is need for development in some of the sector. In this way, the benefits of intra industry trade were recognized.

A research was carried out by Park and Park (2016) on the trade era of MENA ${ }^{\text {ee }}$ s trade by using reforms and RTAs of trade facilitation to revive the trade status of MENA to create more jobs, improve economic growth and welfare. A research was conducted by Cheng (2005) on 44-57 countries with reference to imports and export to deal with the influence of regional alliance on the flow of bilateral symmetric trade. Therefore, the regional and individual agreements along the line of trade are weak. It was discovered that the size of exports and market of China was enhanced after it joined the regional group of ASEANs. Therefore, the researcher pointed that there is no evidence that the export plan of ASEAM was reduced by imports from China. The results revealed that for the export/import, China has been a considered figure in the regional group, which has not restricted the level of intra trade in ASEAN. A research was conducted by Athukorala (2012) on the regional group for development of the economies in the Asia over the years 1985-2008. The research employed standard model of gravity. The forecasting showed that the trade of non-oil products is expected to increase by $8.2 \%$ over the next three decades. However, the share of intra trade in the regional for non-oil products is likely to increase by 53-58\% until 2030. There will be an increase of $39-4 \%$ in the trade to GDP in 2010 and $74.4 \%$ over the next two years.

\subsection{Trade and FDI}

FDI and trade have been proved empirically in different parts of the world such as AU, ACP, and ASEAM. The researcher discovered that the trade is improved by regional integrated by $65 \%$ for EC and for ANDEAN and MERCOSUR 65\% (Bergstrand, Egger, \& Larch, 2016). It was indicated by Glick and Rose (2016) that large effect on intra trade in the region is caused by most RTAs. This research was extended by analyzing the influence of RTAs and it was found that the effect can be positive or negative. It can be either trade diversion or trade creation. Since 1990s, irrespective of the new period of regionalization, the intra-regional trade has not been improved by the new and old blocks. In other words, the intra-regional integration has not been strengthened. Trade diversion has been caused by EFTA and EU. However, the other blocks have resulted in creation of trade. Moreover, new empirical findings were given by (Velde, Page, \& Morrissey, 2017) for Free Trade of the Americans. It revealed that there is a significant influence of preferential tariffs on the agreement of bilateral trade.

FDI is enhanced through Regional Trade Agreements in the region. Moreover, the outcomes of regional trade rules along with FDDI were recognized by Salim, Razavi, and Afshari-Mofrad (2017) to have a deep understanding about the roles of FDI and trade relation to trade barriers. It was found that these are based on the present rules. These can influence the rules, which result in changes for trade and FDI accommodation. The integration can be experienced low or with no effect when the countries and region are merged together. It was indicated by Salim et al. (2017) that efficiency and growth increased with greater regional integration. It was suggested that poor countries can be encouraged to trade in the regional group and investors can be attracted from the outside region. This results in unequal distribution of cost and gains between members of regional integration. An investigation was carried out by using a sample of 71 developing countries between the years 1980-99 to find that FDI has great attraction in these regions. It was indicated that FDI could transfer to RTA countries from nonRTA countries. An increase in the size of market was recorded in the Maghreb region, which enhanced the stock 


\section{ENTREPRENEURSHIP AND SUSTAINABILITY ISSUES}

ISSN 2345-0282 (online) http://jssidoi.org/jesi/

2020 Volume 7 Number 3 (March)

http://doi.org/10.9770/jesi.2020.7.3(42)

of FDI at $165 \%$ Tunisia, $85 \%$ for Morocco, and 62\% for Algeria. Estimation was carried out by Wilson and Bala (2019) through use of estimation model including real stock of FDI for UK and US over the years 1980-2000 among the developing countries. It was found that the regional members were not significant in relation to the FDI inflow. Further, the FDI inflow to the regional group improves with the membership for a specific region and freedom of trade such as foreign firms and trade preferences.

The convergence and divergence is another issue that happens in a region. It was found that size of region and economy of a country reflects the FDI inflow. The closeness of a country and the distance also determines the increase in FDI. The FDI can be improved with closeness in long run such as in the regions of MERCOSUR and NAFTA. For these two groups, there has been increase in FDI as compared to COMESA, ASEAN, which are still in the initial years of investment planning. Some evidences have been given by researchers including Rahmouni and Debbiche (2017) Pain and Lansbury (1996) and Ojide, Chigozie, and Eke (2016) for the influence of RTAs on FDI such as liberalization. The findings of the researchers show that FDI is enhanced by RTs and the results are mix for some region. The expected outcome can be because of region experience with the individual country influences created under the investment planning or trade. There can be size difference in the industrial sector of the countries in a given and the level of openness to the integration, which can be indirect or direct.

\subsection{Theoretical model}

Rybczynski Theorem According to the Rybczynski theorem if the labor-capital ratio differs, then an increase in the endowment of one factor would increase the output of that industry which uses that factor intensively and would result in the reduction of other industry's output, at constant commodity prices. This theory generally accounts for the strategies to target output through factor endowment, with a purpose of analyzing the way resource endowment could affect the output volume. In addition, the factor equalization theorem is an economic theory in which commodity price is used to uniquely determine the factor prices. However, the frictionless trade would only occur in factor price equalization (FPE) among the trading countries, if both countries are identical or possess homogeneous features and technologies and have similar factor endowments.

Boianovsky (2019b) suggested that the chances of factor price equalization (FPE) improves with the increase in output. According to Rajapakse (2019) there are some issues with the Hecksher-Ohlin theory, but this theory has provided useful explanation regarding how income distribution influences through trade. Furthermore, also mentioned the significant role of Hecksher-Ohlin theory in the trade development theory, which has been existing in the literature for the past sixty years. Specific Factor Model (SFM), which is an international trade theory was also proposed for describing how an industry's specific factor of production may influence the trade pattern

During early 1970's, new trade theory has been developed that gave rise to a new trend of describing the process of international trade. Various researchers (Schweighofer-Kodritsch, 2018; Shiny \& McKenzie, 2016) have reexamined this trade theory to modify it through various ways. This theory does not involve the assumption of constant returns to scale and highly depends upon industries with economies of scale. In addition, this theory is based upon two main factors, namely perfect competition and strategic interaction. The theory states that countries should not only trade with other countries on the basis of comparative advantage rather they must also take account of economies of scale and increasing returns to scale.

Similarly, New Economic Geography theory has also been surfaced, aiming to provide a detailed explanation that why industries within certain countries or regions bunch up. This theory assumes that industries generally involve in cluttering because of economic agglomeration. It is commonly viewed as an economic development theory. The New trade theory and New Economic Geography theory have been derived and developed by Paul $R$ Krugman, who received a Nobel prize in Economics in 2008, because of his great contribution in developing these theories. In addition, Vernon product cycle was also surfaced which particularly emphasizes upon 


\section{ENTREPRENEURSHIP AND SUSTAINABILITY ISSUES}

ISSN 2345-0282 (online) http://jssidoi.org/jesi/

2020 Volume 7 Number 3 (March)

http://doi.org/10.9770/jesi.2020.7.3(42)

institutions, such as patenting and intellectual property rights. According to Pearson (2017), such characteristics when combined with homogenous demand may facilitate in developing homogeneous industries. Therefore, those countries with similar features can involve in trade by offering product variety to each other. Those countries having similar demand would tend to trade more as compared to those countries with non-homogenous demand. In international trade, a firm's function is to analyze host economy's supply side. The production function of this theory has a common feature that all factors of production are combined to convert these factors into consumption goods.

A multinational theory refers that a firm operates in more than two countries, and it must offer two types of servicing. Other than exporting alternative, developing a production plan is another alternative to provide services and products in the foreign market. The issues that were identified in basic gravity model have gained the attention of a few researchers. These researchers reexamined this model to develop strong foundation similar to trade model. Thus, in order to resolve issues in basic model, it is important to modify some basic assumptions. For this purpose, Linder (1961) has attempted to resolve and address the issues that were arise in previous model. Similarly, various other researchers have also directed their efforts and attention to develop a theoretical foundation for the gravity model, one of those are Anderson and Van Wincoop (2003) namely the 'gravity with gravitas'. Based on the demand function, Anderson and Van Wincoop (2003) have formulated a gravity model. However, consumer preferences form the basis for a constant elasticity of substitution. Thus, there must be 'love for variety' among consumers, signifying that consuming differentiated products increase consumer utility. On the production side, Krugman (1979) put forward some basic assumptions, stating that each firm must be capable of producing unique product variety to obtain increasing returns to scale.

This assumption allows firms to involve in fixed mark-up pricing and vanishes the assumption of fundamental interactions, competition, and large number of firms. When equilibrium is established, the difference of price and marginal cost equals the fixed cost required for entering into the market. It is the producer who decides whether to sell goods in local or foreign market. For model simplification, it is assumed that local product selling would not involve any transportation cost whereas, selling same product in foreign market would involve the transportation cost. On the other hand, consumers can purchase variety of products both from local and international markets. However, the internationally produced product price would involve the cost of transporting goods from one to the other country. The derivation of this model is the building block which provide the grounds for achieving equilibrium position, at this point local and international firms and producers transact with each other. The basic gravity model enables to contemplate each firm's total export volume. Combining all firms in a country allows to derive a country's total value of exports, which acts as dependent variable in the gravity model

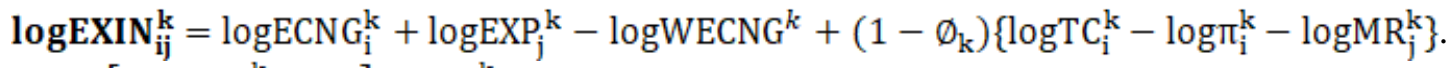

$$
\begin{aligned}
& \mathbf{\pi}_{\mathbf{i}}^{\mathbf{k}}=\left[\sum_{j=1}^{c}\left(\frac{\mathrm{TC}_{i}^{\mathrm{k}}}{\mathrm{MR}_{\mathrm{j}}^{\mathrm{k}}}\right)^{1-\emptyset_{\mathrm{k}}}\right] * \frac{\mathrm{EXP}_{1}^{\mathrm{k}}}{\mathrm{ECNG}^{k}} \ldots(2) \\
& \mathbf{M R}_{\mathbf{j}}^{\mathbf{k}}=\left[\sum_{j=1}^{c}\left(\frac{\mathrm{TC}_{\mathrm{i}}^{\mathrm{k}}}{\pi_{\mathrm{i}}^{\mathrm{k}}}\right)^{1-\emptyset_{\mathrm{k}}}\right] * \frac{\mathrm{ECNG}_{\mathrm{i}}^{\mathrm{k}}}{\mathrm{ECNG}^{k}} \ldots
\end{aligned}
$$

Where, EXIN is teh export of the index, ECNG is the economic growth, WECNG $^{k}=\sum_{i=1}^{c} \mathrm{ECG}_{\mathrm{i}}^{\mathrm{k}}$ is the world economic growth, EXP represents expenditures as percentage of GDP, $\emptyset_{\mathrm{k}}$ is the elasticity of substitution of intrasectoral between varieties, TC represents trade cost, $\pi_{\mathrm{i}}^{\mathrm{k}}$ reprints the outward multilateral resistance that captures all export from country $i$ to country $\mathrm{j}$ depending on the trade cost across all potential export markets, and finally $\mathrm{MR}_{\mathrm{j}}^{\mathrm{k}}$ inward multilateral resistance that captures that import dependency from country $\mathrm{j}$ to country $\mathrm{i}$ depending on trade costs from the potential suppliers. 


\section{ENTREPRENEURSHIP AND SUSTAINABILITY ISSUES}

ISSN 2345-0282 (online) http://jssidoi.org/jesi/

2020 Volume 7 Number 3 (March)

http://doi.org/10.9770/jesi.2020.7.3(42)

Combinations of these two terms remain the key to the model and successfully correct the problem facing intuitive gravity model. In all bilateral routes, the multilateral resistance terms require trade costs. The relative price change of one route can affect the trade flow of other routes. Since the previous intuitive gravity model does not include outward and inward multilateral resistance variables but they are correlated with trade cost. Even there is evidence of classic omission of variables biasness in intuitive gravity model i.e. other variables that directly affect trade.

However, the following key points are to be taken into consideration for gathering data under theoretical gravity model. Some literatures used dependent variables as logarithm of total trade for a country i.e. the addition of imports and exports or rather they use the average of exports in both ways. Theoretical gravity model indicated that such an approach might leads to misleading or confusing results; hence, the direction of each trade should be in a single flow (unidirectional export flows). For instance, export from Nigeria to Benin should be recorded in a single line, and export from Benin to Nigeria should be recorded in a single line too. That is for a country pair. The second observation noticed in the literature is whether trade values should be reported in real or nominal terms, there is no serious issue regarding that but at the same time we needs to take note if we are using cross sectional gravity model or time series in order to determine which one to use. As for cross -sectional no issue using trade values reported in real or nominal terms because regardless of any scaling used whether uniform or factor applied, the result will still be the same.

However, as for time series the answer is straight and clear because in line with the theory, trade flows should not be in real terms rather it should be in nominal terms. This is due to the fact that export are usually deflated under the two multilateral resistance e.g. GDP deflator or CPI (prices indices or deflating export) cannot be adequately identify the unobserved multilateral resistance, which can leads to misleading results. Another aspect to take note is the GDP data, where it should be in nominal and not real terms.

Since they are also deflated with the multilateral resistance terms, i.e. unobserved price indices, also deflated by price index that is observable and other factors might likely lead to misleading results. Gravity model make it clear to include sectoral expenditure including output rather than GDP. Furthermore, this is impossible to prove empirically especially when developing nation are included. Gravity model specification must include trade costs for estimation purpose i.e. trade costs. In literatures, this function is specified as a term of observable variables, which is assumed to be affecting trade costs when using log-linear specification in a simple form, hence we can generate trade costs function as:

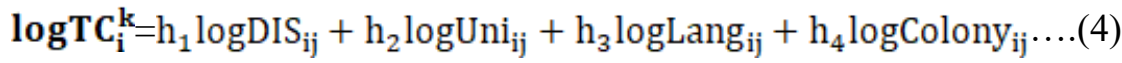

Where, DIS represents geographical distance between two countries, Uni measures unity between countries with the same land border, Lang represents countries with the same language that is officially recognise , and Colony represents countries that share the same colonial relationship These formulations represent a typical gravity model, which is in line with the literatures of gravity model; this particular model has been described as a significant determinant of bilateral trade. Most researchers argue to include policy related variables. Another important issue to take note is that trade cost cannot be separated from elasticity of substitution i.e. elasticity of trade cost (h term) during estimations. Hence the two must be multiplied together, it was suggested that we need to be very careful when interpreting the estimated coefficient differences concerning different sensitivity level on various sectors under trade cost factors. For us to find the elasticity of pure trade cost, there is a need to interact cost variables with substitution of elasticity when estimating, whether using model-based estimates or general assumption. According to scholar, in application most researchers do not follow it. 
$\boldsymbol{U}_{\mathbf{i}}=\sum_{i=0}^{k}\left[\int_{D e v_{i}^{k}}^{1}\left\{Z_{\mathrm{i}}^{\mathrm{k}}(\text { ver })\right\}^{\left.1 \frac{1}{d z_{d V E R}}\right]^{\frac{1}{\mathrm{C}_{\mathrm{k}}}}}\right.$

$U_{\mathrm{i}}=$ Represent different varieties consumed by country $\mathrm{I}$ while $\mathrm{Z}_{\mathrm{i}}^{\mathrm{k}}($ ver $)$ signifies the amount of variety $\mathrm{v}$ consumed from sector $\mathrm{k}$ in country $\mathrm{I}$, thus $\mathrm{MR}_{\mathrm{i}}^{\mathrm{k}}(U)$ represent the unit price. $\mathrm{V}$ symbol represent (discrete number of varieties) a subscript and integrals replaced by sums. The total sums of sectoral utilities represent the utility function, which is equally weighted. The restriction can be removed by adding the entire subsector or sectoral utilities using Cobb-Douglas function of utility, while accommodating different weights. The tendency of existence of exogenous depends on the longer shares of the model. This is in line with other basic result such as: Chaney (2008) is a typical example of what alternative expression look like. Anderson and Van Wincoop (2003), consider using a single sector in order to avoid cluttering up the algebra with more indices. However, putting this issue into consideration it is very important to consider disaggregation of some sectors in order to critically examine the other key implications of data that flows from the model using multi-sector circumstances.

$\boldsymbol{E} \boldsymbol{X} \boldsymbol{P}_{\mathrm{i}}=\left(\sum_{i=0}^{k}\left[\int_{(\mathrm{V} * E X P * U)_{i}^{k}}^{1}\left\{\mathrm{MR}_{\mathrm{i}}^{\mathrm{k}}(U)\right]\right) * \mathrm{Z}_{\mathrm{i}}^{\mathrm{k}}(v e r) d v=\sum_{k=1}^{k} E X P_{i}^{k} \ldots(6)\right.$

Consumers are faced with the problem of what to choose concerning in $v$ in order to maximize equation (2.7) in relation to (2.8). The Lagrangian can be stated as follows:

$\boldsymbol{L N} \boldsymbol{G}=\left(\sum_{i=0}^{k}\left[\int_{(\mathrm{V} * E X P * U)_{i}^{k}}^{1}\left\{\mathrm{Z}_{\mathrm{i}}^{\mathrm{k}}(v e r)\right\}^{\left.1 \frac{1}{d z_{d V E R}}\right]^{\frac{1}{\mathrm{I}_{\mathrm{k}}}}}\right)-\left(\eta \sum_{i=0}^{k}\left[\int_{(V * E X P * U)_{i}^{k}}^{1}\left\{\mathrm{MR}_{\mathrm{i}}^{\mathrm{k}}(U) * \mathrm{Z}_{\mathrm{i}}^{\mathrm{k}}(v e r) d v\right) \ldots\right.\right.\right.$

Assuming first order condition concerning quantity with the aim of setting it to zero will gives:

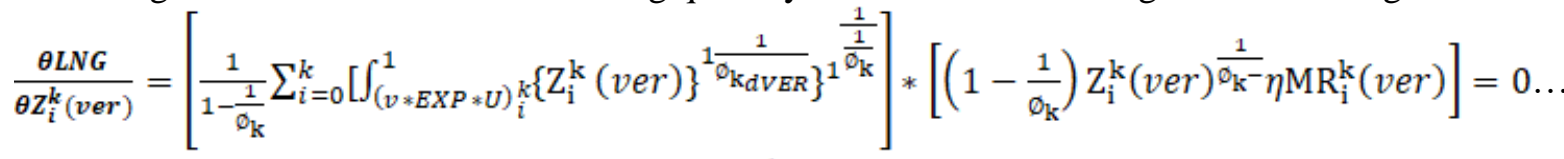

Determine $\sum_{i=0}^{k}\left[\int_{(v * E X P * U)_{i}^{k}}^{1}\left\{\mathrm{Z}_{\mathrm{i}}^{\mathrm{k}}(v e r)\right\}^{\left.1 \frac{1}{\varrho_{\mathrm{k}_{d V E R}}}\right\}^{\frac{1}{\varphi_{\mathrm{k}}}}}\right.$, rearrange, and regroup the terms to show

$\eta \mathbf{M} \mathbf{R}_{\mathbf{i}}^{\mathbf{k}}($ ver $)=\left[\frac{\left.\mathrm{z}_{i}^{\mathrm{k}}(\text { ver })\right\}^{\frac{1}{\eta}}}{\int_{(v * E X P * U)_{i}^{k}}^{1} \mathrm{z}_{i}^{\mathrm{k}(v e r)\}^{1} \frac{1}{d z_{d V E R}}}}\right] * E^{1} X I N^{k} \ldots(9)$

Rearrange once again, total all kinds together in a sector, then multiply all by the prices by applying Lagrangian multiplier to solve the problem

$\left[\theta \mathbf{M R}_{\mathbf{i}}^{\mathbf{k}}(\right.$ ver $\left.)\right] * \mathbf{Z}_{\mathrm{i}}^{\mathbf{k}}($ ver $)$

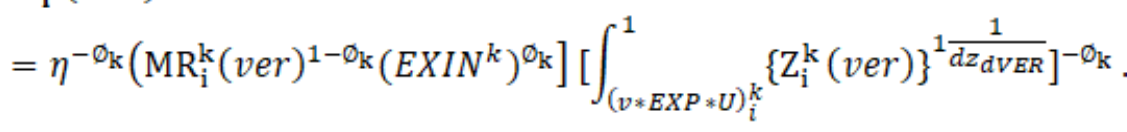

$\int_{(V * E X P * U)_{i}^{k}}^{1}\left\{\operatorname{MR}_{\mathbf{i}}^{\mathbf{k}}(U) * \mathbf{Z}_{\mathrm{i}}^{\mathrm{k}}(v e r) d v=\operatorname{EXP}_{\mathrm{i}}^{\mathrm{k}}\right.$

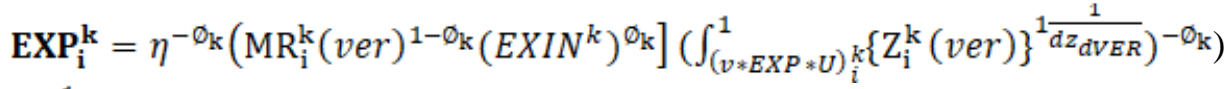

$* \int_{(v * E X P * U)_{i}^{k}}^{1}\left\{\mathrm{Z}_{\mathrm{i}}^{\mathrm{k}}(v e r) 1^{\oplus_{\mathrm{k}}} d v . .(12)\right.$

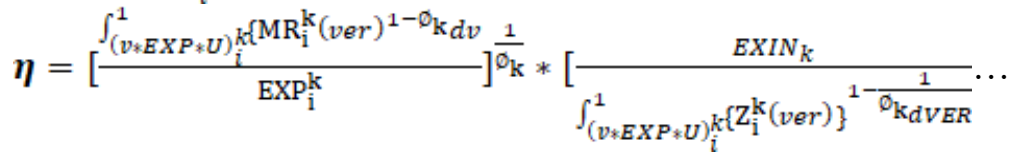

Therefore, to obtain a demand function, substitution method needs to be applied by substituting the Lagrangian multiplier back to first order condition of equation (11): 


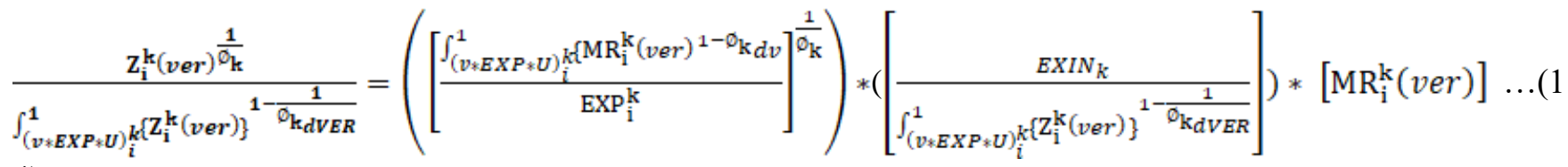

4)

$$
\begin{aligned}
& \mathbf{Z}_{\mathrm{i}}^{\mathbf{k}}(\text { var })=\left(\frac{\left[\mathrm{MR}_{\mathrm{i}}^{\mathrm{k}} \text { (ver) }\right]^{-\emptyset_{\mathrm{k}}}}{\mathrm{Z}_{\mathrm{i}}^{\mathrm{k}}(\text { ver })}\right) * \operatorname{EXP}_{\mathrm{i}}^{\mathrm{k}} \ldots \ldots . . \\
& \mathbf{Z}_{\mathrm{i}}^{\mathbf{k}}(\text { var })=\left(\frac{\left[\mathrm{MR}_{\mathrm{i}}^{\mathrm{k}}(\text { ver })\right]^{-\emptyset_{\mathrm{k}}}}{\mathrm{Z}_{\mathrm{i}}^{\mathrm{k}}}\right) *\left(\frac{\operatorname{EXP}_{\mathrm{i}}^{\mathrm{k}}}{\mathrm{Z}_{\mathrm{i}}^{\mathrm{k}}}\right) \ldots \ldots
\end{aligned}
$$

Where, $\int_{\left(v * E X P^{*}\right)_{i}^{k}}^{1}\left\{M R_{i}^{k}(v e r)^{1-\emptyset_{k}} d v\right\}^{\frac{1}{1-\emptyset_{k}}}=\mathrm{MR}_{\mathrm{i}}^{\mathrm{k}}$ represent CES price index for sector $\mathrm{k}$ in country i. The problem facing produceres $\mathrm{s}$ in this model is how to maximize profit at minimum cost. Assuming large number of firms, strategic interaction disappears, markup of firm charges remains constant under the general model. In this section, equilibrium pricing equation and equilibrium demand equation formulated in the previous section will be used to generate gravity model, then each country i measure for all active firms regarding sector also all the firms are differentiated with unique product. To measure the aggregate of the worldwide product for each sector is $\sum_{i=1}^{c} N_{i}^{k}$.Per unit of product produce; each firm will have to pay a certain sum of amount which is fixed cost $f c_{i}^{k}$ with a variable $\operatorname{cost} v c_{i}^{k}$ at .wage rate $w r_{i}^{k}=$. Therefore, a firm ${ }^{e e}$ s profit is specified as:

$\boldsymbol{\pi}_{\mathrm{i}}^{\mathrm{k}}($ var $)=\left[\mathrm{MR}_{\mathrm{i}}^{\mathrm{k}}(\right.$ var $) * \mathrm{Z}_{\mathrm{i}}^{\mathrm{k}}($ var $\left.)\right]-\left[\left(\mathrm{MR}_{\mathrm{i}}^{\mathrm{k}} * \mathrm{wr}_{\mathrm{i}}^{\mathrm{k}} * \mathrm{vc}_{\mathrm{i}}^{\mathrm{k}}\right)(\right.$ ver $\left.)\right]-\left[\mathrm{wr}_{\mathrm{i}}^{\mathrm{k}} * \mathrm{fc}_{\mathrm{i}}^{\mathrm{k}}\right] \ldots$

Under different varieties, we do not need to assume whether to use quantity or Bertrand (price) competition. Therefore, if Bertrand plays out, then first order condition hold:

$\frac{\rho \pi_{\mathrm{i}}^{\mathrm{k}}(\text { var })}{\rho \mathrm{R}_{\mathrm{i}}^{\mathrm{k}}(\text { var })}=\mathrm{Z}_{\mathrm{i}}^{\mathrm{k}}($ var $)+\mathrm{MR}_{\mathrm{i}}^{\mathrm{k}}($ var $) \frac{\rho \mathrm{Z}_{\mathrm{i}}^{\mathrm{k}}(\text { var })}{\rho \mathrm{MR} \mathrm{R}_{\mathrm{i}}^{\mathrm{k}}(\text { var })}-(\text { wr *vc) })_{\mathrm{i}}^{\mathrm{k}} \frac{\left.\rho \mathrm{Z}_{\mathrm{i}}^{\mathrm{k}} \text { (var }\right)}{\rho \mathrm{MR} \mathrm{R}_{\mathrm{i}}^{\mathrm{k}}(\text { var })}=0$

to solve for prices:

To adjust the expression above, explanation on partial is needed, evaluation with the use of demand function of equation (17) is considered, taking note of large group based on assumption. Therefore, any slight change in any firm's price (one) will not affect the general price level of the sector because many firms are in competition. In view of this, the equation can be written as

$\mathbf{Z}_{\mathrm{i}}^{\mathbf{k}}($ var $)=(w r * v c)_{\mathrm{i}}^{\mathrm{k}} \frac{\mathrm{z}_{\mathrm{i}}^{\mathrm{k}}(\text { var })}{\frac{\rho \mathrm{Z}_{\mathrm{i}}^{\mathrm{k}}(\text { var })}{\left.\rho \mathrm{MR} \mathrm{K}_{\mathrm{i}}^{\mathrm{k}}(\text { var })\right]}} \ldots$

Using first order condition under profit maximization, we can rewrite the equation as:

$\mathbf{Z}_{\mathrm{i}}^{\mathbf{k}}($ var $)=(\text { wr } * \text { vc })_{\mathrm{i}}^{\mathrm{k}}+\mathrm{Z}_{\mathrm{i}}^{\mathrm{k}}($ var $) \frac{\mathrm{MR}_{\mathrm{i}}^{\mathrm{k}}(\text { var })}{\theta_{k} \mathrm{Z}_{\mathrm{i}}^{\mathrm{k}}(\text { var })} \ldots \ldots$

If we rearrange and solved for price the equation is going to give:

$\mathbf{Z}_{\mathrm{i}}^{\mathrm{k}}($ var $)=\frac{1}{\theta_{k}} \mathrm{Z}_{\mathrm{i}}^{\mathrm{k}}($ var $)=\mathrm{Z}_{\mathrm{i}}^{\mathrm{k}}($ var $)\left(1-\frac{1}{\theta_{k}}\right)=(\text { wr } * \text { vc })_{\mathrm{i}}^{\mathrm{k}} \ldots \ldots$

$\mathbf{Z}_{\mathrm{i}}^{\mathbf{k}}($ var $)=\left(\frac{\theta_{k}-1}{\theta_{k}}\right)(w r * v c)_{\mathrm{i}}^{\mathbf{k}} \ldots$

The firm's marginal cost of production is on the right-hand side of equation (24). Bracket represent the constant markup with the sector, it is assumed that the numerator must be greater than the denominator, in view of this positive wedge existing between marginal cost, price and factory firm's gate. It is assumed that wedge rely on elasticity of substitution of sectors which is constant to all firms under this sector. If the same good produced by country $i$ is consumed by country $j$ then marginal cost is under this assumption, costless trade must match with while must match additional one including ad valorem tariff rate. Therefore, trade friction is linked with a particular coefficient but does not depend on the size of goods shipped. Hence iceberg costs are treated as variable 


\section{ENTREPRENEURSHIP AND SUSTAINABILITY ISSUES}

ISSN 2345-0282 (online) http://jssidoi.org/jesi/

2020 Volume 7 Number 3 (March)

http://doi.org/10.9770/jesi.2020.7.3(42)

cost but not fixed. Under any given two countries i.e. county $i$ and $j$, iceberg trade cost means that country $j$ rice of goods that was produced in country $i$ is from equation (24) as shown above:

$\mathbf{Z}_{\mathrm{i}}^{\mathrm{k}}($ var $)=\left(\frac{\theta_{k}-1}{\theta_{k}}\right) \mathrm{TC}_{\mathrm{ij}}^{\mathrm{k}}(w r * v c)_{\mathrm{i}}^{\mathrm{k}} \ldots$

If we rewrite the country price index into a general form:

$\mathbf{Z}_{\mathbf{i}}^{\mathbf{k}}($ var $)=\int_{(v * E X P * U)_{i}^{k}}^{1}\left\{\left(\mathrm{TC}_{\mathrm{ij}}^{\mathrm{k}} * M R_{i}^{k}\right)(\text { ver })^{1-\emptyset_{k}} d v\right\}^{\frac{1}{1-\emptyset_{k}}} \ldots$

Conditions to take note, the country price index include different varieties produced and consumed by the same country. This means a set to unity, in order to show the absence of likely barrier faced by internal trade.

\section{Model estimation}

The long run relationship has been examined and analyzed through the use of Johansen cointegration method. This approach was developed by Johansen and Juselius (1990). The method revolutionized way of estimating long run and short run relationship for multivariate equation. It has the advantage over Engle and Granger (1987) approach in that it tests for cointegration by determining the cointegrating vectors and number of cointegrating vectors between the variables. Johansen and Juselius method also consider all variables as latent endogenous variables, thereby averting the exogeneity problem. In addition, Johansen and Juselius model can estimate the causal relationship between variables as the causality estimation is embedded in VECM. Lastly, it uses maximum eigenvalue and trace statistics in determining the number of cointegrating relationships with expected signs of the coefficients. Engle and Granger approach determines the cointegration by testing the stationarity of the residual only.

The Johansen cointegration approach has the ability of expanding single equation for an error correction model to multivariate equation. Suppose that the $\mathrm{CO}_{2}$ emission is represented by $Z_{t}$, political freedom $W_{t}$, economic freedom $X_{t}$ by and GDP growth by $Y_{t}$ take the form as

$Z_{t}=\left[Y_{t}, X_{t}, W_{t}\right] \ldots(25)$

The AR model of equation can be

$Z_{t}=A_{1} Z_{t-1}+A_{2} Z_{t-2} \ldots . . A_{k} Z_{t-k}+\varepsilon_{t} \ldots \ldots \ldots \ldots \ldots \ldots$ (26)

Equation (26) may be altered to VECM as given in equation (27)

$\Delta Z_{t}=\Gamma_{1} \Delta Z_{t-1}+\Gamma_{2} \Delta Z_{t-2} \ldots . \Gamma_{k-1} \Delta Z_{t-k-1}+\Pi Z_{t-k}+\varepsilon_{t}$

Where, $\Gamma_{1}=\left[\mathrm{I}-A_{1}-A_{2}-\cdots A_{k}\right], i=1,2,3 \ldots k-1$

$\Pi=-\left(\mathrm{I}-A_{1}-A_{2}-\cdots A_{k}\right)$

Therefore, $\Pi$ is a 3 by 3 matrix because of assumed three variables. This can be broken as $\Pi=\alpha \beta$ where $\alpha$ contains the speed of adjustment towards equilibrium. Whereas the $\beta$ is the long run coefficient., and $\beta Z_{t-1}$ is an error correction term. For a simplistic example, takes $\mathrm{k}=2$ equation (28) can be written as

$\left[\begin{array}{l}\Delta Y_{t} \\ \Delta X_{t} \\ \Delta W_{t}\end{array}\right]=\Gamma_{t}\left[\begin{array}{l}\Delta Y_{t-1} \\ \Delta X_{t-1} \\ \Delta W_{t-1}\end{array}\right]+\left[\begin{array}{ll}\alpha_{11} & \alpha_{12} \\ \alpha_{21} & \alpha_{22} \\ \alpha_{31} & \alpha_{32}\end{array}\right]\left[\begin{array}{ccc}\beta_{11} & \beta_{12} & \beta_{13} \\ \beta_{21} & B \beta_{22} & \beta_{23}\end{array}\right]\left[\begin{array}{l}\Delta Y_{t-1} \\ \Delta X_{t-1} \\ \Delta W_{t-1}\end{array}\right]+\varepsilon_{t} \ldots \ldots$.

the equation (29) can be written as

$\Pi_{I} Z_{t}=\left[\alpha_{11} \beta_{11}+\alpha_{21} \beta_{21}\right]\left[\alpha_{21} \beta_{12}+\alpha_{22} \beta_{22}\right]\left[\alpha_{31} \beta_{13}+\alpha_{32} \beta_{23}\right]\left[\begin{array}{c}Y_{t-1} \\ X_{t-1} \\ W_{t-1}\end{array}\right] \ldots \ldots \ldots \ldots . .$.

The equation can be transformed into yield equation as

$\Pi_{i} Z_{t-1}=\alpha_{11}\left(\beta_{11} Y_{t-1}+\beta_{21} X_{t-1}+\beta_{31} W_{t-1}\right)+\alpha_{12}\left(\beta_{12} Y_{t-1}+\beta_{22} X_{t-1}+\beta_{32} W_{t-1}\right) \ldots .(31)$.

According to Enders (2004) $\alpha_{11}$ and $\alpha_{12}$ are speed of adjustment terms

Mathematical equation above can be incorporated into statistics just by including error term and then apply logarithm to the whole equation. Ordinary least square can also be used to estimate the model above. Cross section data can be used when bringing in trade relationship and trade effect in a particular period using classical model of gravity. Important information can find using cross section data over long period of time (panel 


\section{ENTREPRENEURSHIP AND SUSTAINABILITY ISSUES}

ISSN 2345-0282 (online) http://jssidoi.org/jesi/

2020 Volume 7 Number 3 (March)

http://doi.org/10.9770/jesi.2020.7.3(42)

methodology) compare with cross section data only. There are various advantages attached to this method. Panel has the capability to capture applicable relationship between variables of interest over period of time. Another important feature of panel is that it can monitor unperceivable /unobservable trading partner pairs i.e. individual effect. Ordinary least square estimates exclude individual effect that causes biasness only when the individual effects are correlated to the regressors. Hence, panel methodology is employed using empirical gravity trade model. Gravity trade model states that distance (procurator for cost of transportation), GDP or GNP, each country population, culture similarities, GDP per capita, other economic factors and other variables which are dummy speak more about the bulk of trade whether import or export between countries Xij (pairs). Key variables included in the gravity model can either restrain or spur trade among countries of pairs. In order to answer specific objective, one as stated above, export model is depicted below.

$\ln E X P_{i t j t}=$

$\alpha_{1} \operatorname{lnDIS}_{\text {itjt }}+\alpha_{2} \operatorname{lnECNG}_{\text {itjt }}+\alpha_{3} \operatorname{lnECNG}_{\text {itjt }}+\alpha_{3} \operatorname{lnUni}_{\text {itjt }}+\alpha_{4} \operatorname{lnLang}_{\text {itjt }}+\alpha_{5} \operatorname{lnColony}_{\text {itjt }}+$ $+\alpha_{6} \ln R_{\text {itjt }}+\alpha_{7} \ln$ TROP $_{\text {itjt }}+\alpha_{8} \operatorname{lnASEAN}_{\text {itjit }}+\varepsilon_{i t j t}$

....(32)

$\ln$ MPORT $_{\text {itjt }}=$

$\alpha_{1} \operatorname{lnDIS}_{\mathrm{itjt}}+\alpha_{2} \operatorname{lnECNG}_{\mathrm{itjt}}+\alpha_{3} \operatorname{lnWECNG}_{\mathrm{itjt}}+\alpha_{3} \operatorname{lnUni}_{\mathrm{itjt}}+\alpha_{4} \operatorname{lnLang}_{\mathrm{itjt}}+\alpha_{5} \operatorname{lnColony}_{\mathrm{itjt}}+$ $+\alpha_{6} \operatorname{lnPR}_{\text {itjt }}+\alpha_{7} \operatorname{lnTROP}_{\text {itjt }}+\alpha_{g} \operatorname{lnASEAN}_{\text {itjt }}+\varepsilon_{i t j t}$

....(33)

In order to answer objective one and two, a trade model for the entire market was proposed for ASEAN nations. In order to achieve the study's objectives, the following steps were taken in order to achieve unbiased estimation results.

$\ln I M P O R T_{i t j t}=$ $\alpha_{1} \operatorname{lnDIS}_{\mathrm{itjt}}+\alpha_{2} \operatorname{lnECNG}_{\mathrm{itjt}}+\alpha_{3} \operatorname{lnWECNG}_{\mathrm{itjt}}+\alpha_{3} \operatorname{lnUni}_{\mathrm{itjt}}+\alpha_{4} \operatorname{lnLang}_{\mathrm{itjt}}+\alpha_{5} \operatorname{lnColony}_{\mathrm{itjt}}+$ $+\alpha_{6} \operatorname{lnPR}_{\text {itjt }}+\alpha_{7} \operatorname{lnTROP}_{\text {itjt }}+\alpha_{8}$ ngASEAN $_{\text {itjt }}++\alpha_{9} \operatorname{lnBLT}_{\text {itjt }}+\sum_{r} \beta_{10} \operatorname{lnASEAN} *$ BLT $_{\text {itjt }}+\varepsilon_{i t j t}$ ....(34)

This model examines the impact of institutional quality on ASEAN trade. Looking beyond the major determinants to examine the likely impacts of institution on ASEAN trade is imperative. The following steps were taken in order to achieve the fourth objective. Estimation technique employed was the Poisson pseudo-maximum likelihood estimation (PPML). This method was introduced into gravity modeling to capture the zero-trade matrix that usually occurs in trade (Export and Import). Sousa (2012) designed the method to capture zero trade matrixes, which is part of the nonlinear method of estimation. At default PPML estimation techniques are semi robust against likely bias. Our focus here is mainly on three variables, namely, the corruption index, political instability, and regulatory quality. In order to answer specific objective four-export model of gravity below is here by proposed.

$\ln E X P_{\text {itjit }}=$

$\alpha_{1} \operatorname{lnDIS}_{\mathrm{itjt}}+\alpha_{2} \operatorname{lnECNG}_{\mathrm{itjt}}+\alpha_{3} \operatorname{lnWECNG}_{\mathrm{itjt}}+\alpha_{3} \operatorname{lnUni}_{\mathrm{itjt}}+\alpha_{4} \operatorname{lnLang}_{\mathrm{itjt}}+\alpha_{5} \operatorname{lnColony}_{\mathrm{itjt}}+$

$+\alpha_{6} \ln R_{\text {itjt }}+\alpha_{7} \operatorname{lnTROP}_{\text {itjt }}+\alpha_{8} \operatorname{lncorup}_{\text {itjt }}+\alpha_{9} \operatorname{lnPIN}_{\text {itjt }}+\varepsilon_{i t j t}$

\section{Results}

The correlational analysis of the variables is shown in the table 1 . The correlation value indicates that the all the variables used in the current study are highly correlated. The correlation between trade openness (TO), market openness (MO), Price stability (PRS), HDP growth (GDPG) and political stability (POLT) are shown in table 1. 
The first and foremost in the Johansen cointegration test is that optimal lag length must be determined. The optimal lag length should be such that sufficient to be with white noise. Optimal lag length for obtaining the Johansen cointegration is based on the Vector Autoregressive Model (VAR). Then, lag order is obtained according to the information criteria (Enders, 2004).

Table 1. Correlations

\begin{tabular}{|c|c|c|c|c|c|c|c|c|c|c|c|c|c|c|c|}
\hline & & 1 & 2 & 3 & 4 & 5 & 6 & 7 & 8 & 9 & 10 & 11 & 12 & 13 & $\begin{array}{l}1 \\
4\end{array}$ \\
\hline $\operatorname{Lag}(\operatorname{lnDIS})$ & 1 & 1 & & & & & & & & & & & & & \\
\hline $\begin{array}{l}\text { Lag } \\
\text { (lnECNG) }\end{array}$ & 2 & -0.1830 & 1 & & & & & & & & & & & & \\
\hline $\begin{array}{l}\text { Lag(LnWEC } \\
\text { NG) }\end{array}$ & 3 & -0.0257 & 0.1483 & 1 & & & & & & & & & & & \\
\hline Lag(InUni) & 4 & -0.0810 & 0.1188 & 0.8929 & 1 & & & & & & & & & & \\
\hline Lag(lnLng) & 5 & 0.1456 & $\begin{array}{l}- \\
0.4363\end{array}$ & 0.1129 & 0.0579 & 1 & & & & & & & & & \\
\hline $\begin{array}{l}\text { Lag(lnColony } \\
\text { ) }\end{array}$ & 6 & 0.1308 & $\begin{array}{l}- \\
0.2847\end{array}$ & $\overline{-}-0828$ & $\begin{array}{l}- \\
0.0674\end{array}$ & 0.0882 & 1 & & & & & & & & \\
\hline $\operatorname{Lag}(\operatorname{lnPR})$ & 7 & 0.0220 & 0.2994 & $\begin{array}{l}- \\
0.1216\end{array}$ & $\begin{array}{l}- \\
0.0935\end{array}$ & $\begin{array}{l}-3391 \\
0.33\end{array}$ & $\begin{array}{l}- \\
0.0720\end{array}$ & 1 & & & & & & & \\
\hline Lag(InTROP) & 8 & 0.02310 & 0.2188 & 0.3929 & 0.1057 & 0.1057 & 0.2157 & 0.2474 & 1 & & & & & & \\
\hline Lag(Incorup) & 9 & 0.23456 & $\begin{array}{l}- \\
0.2363\end{array}$ & 0.3129 & 0.2674 & 0.2674 & 0.2474 & 0.3474 & 0.1721 & 1 & & & & & \\
\hline $\operatorname{Lag}(\ln P I N)$ & 10 & 0.2308 & 0.2347 & $\begin{array}{l}- \\
0.2828\end{array}$ & 0.2935 & 0.2935 & 0.1535 & 0.2345 & 0.2981 & 0.1826 & 1 & & & & \\
\hline $\begin{array}{l}\operatorname{Lag}(\ln \mathrm{ASEA} \\
\mathrm{N})\end{array}$ & 11 & 0.1220 & 0.2239 & $\begin{array}{l}- \\
0.1321\end{array}$ & 0.1674 & 0.1674 & 0.1874 & 0.1276 & 0.2019 & 0.2374 & 0.1765 & 1 & & & \\
\hline $\operatorname{Lag}(\operatorname{lnBLT})$ & 12 & 0.2341 & 0.1872 & 0.1634 & 0.2235 & 0.2235 & 0.1235 & 0.1321 & 0.2301 & 0.7651 & 0.3235 & 0.2654 & 1 & & \\
\hline $\begin{array}{l}\text { Lag } \\
\text { (lnIMPORT) }\end{array}$ & 13 & 0.2323 & 0.4321 & $\begin{array}{l}- \\
0.3761\end{array}$ & 0.1674 & 0.2376 & 0.4327 & 0.3751 & 0.6541 & 0.8210 & 0.5482 & 0.7901 & $\begin{array}{l}0.7862 \\
1\end{array}$ & 1 & \\
\hline 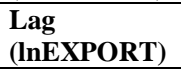 & 14 & 0.2391 & 0.4871 & 0.2651 & 0.2235 & 0.4321 & 0.5431 & 0.7651 & 0.4311 & 0.0761 & 0.8631 & 0.8730 & $\begin{array}{l}0.5430 \\
1\end{array}$ & $\begin{array}{l}0.3402 \\
1\end{array}$ & 1 \\
\hline
\end{tabular}

As vividly seen in Table 2, different information criteria suggested different optimal lag for cointegration. Akaike Information Criterion (AIC) chose two lag while Schwartz Information Criterion (SIC) suggested lag one. The two lags as suggested by AIC has been used. The aim is to have parsimonious and best results.

Table 2. Lag Length Selection Criterion

\begin{tabular}{|l|l|l|l|l|l|}
\hline Lag & LogL & LR & FPE & AIC & SC \\
\hline 0 & -730.929 & NA & $4.05 \mathrm{e}+12$ & 46.058 & 46.332 \\
\hline 1 & -624.659 & $166.047^{*}$ & $5.24 \mathrm{e}+10^{*}$ & 41.667 & $43.590^{*}$ \\
\hline 2 & -585.566 & 46.418 & $5.58 \mathrm{e}+10$ & $41.473^{*}$ & 45.046 \\
\hline
\end{tabular}

Note: LR: sequence modified LR test statistics; FPE: final prediction error AIC: Akaike information criterion; SC: Schwarz information criterion HQ: Hannan-Quinn information criterion. * denote choice of lag.

Cointegration is all about long run relationship, among at least two variables which are non-stationary. The test for cointegration requires that the variables be integrated of the same order. The Johansen test uses trace test and maximum eigenvalue test determine the number of cointegrating equation. Table 3 presents the cointegration results. 
ENTREPRENEURSHIP AND SUSTAINABILITY ISSUES

ISSN 2345-0282 (online) http://jssidoi.org/jesi/

2020 Volume 7 Number 3 (March)

http://doi.org/10.9770/jesi.2020.7.3(42)

Table 3. Johansen cointegration test

\begin{tabular}{|c|c|c|c|}
\hline $\begin{array}{l}\text { Dependent } \\
\mathrm{CO}_{2}\end{array}$ & Model 1 & Model 2 & Model 3 \\
\hline $\operatorname{Lag}(\operatorname{lnDIS})$ & $0.0177 * * *$ & $0.3421 * * *$ & $0.2189 * *$ \\
\hline Lag (InECNG) & $0.2371 * * *$ & $0.9531 * *$ & $0.2441 * *$ \\
\hline Lag(LnWECNG) & $0.0198 * *$ & $0.0154 * *$ & $0.2170 * * *$ \\
\hline $\operatorname{Lag}(\ln U n i)$ & $0.0272 * *$ & $0.3951 * * *$ & $0.1493 * * *$ \\
\hline Lag(lnLng) & $0.0254 * *$ & $0.0238 * * *$ & $0.1243 * * *$ \\
\hline Lag(InColony) & $0.01432 * * *$ & $0.2281 * * *$ & $0.2711^{*}$ \\
\hline $\operatorname{Lag}(\operatorname{lnPR})$ & $0.0222 * *$ & $0.0313 * *$ & $0.1284 *$ \\
\hline Lag(lnTROP) & $0.1761 * *$ & $0.0743^{* *}$ & $0.2132 * *$ \\
\hline Lag(Incorup) & $0.0797 * *$ & $0.0488^{*}$ & $0.2633 * * *$ \\
\hline $\operatorname{Lag}(\ln P I N)$ & $0.0332 * * *$ & $0.0943 * *$ & $0.1980 * *$ \\
\hline $\operatorname{Lag}(\ln A S E A N)$ & $0.0177 * * *$ & $0.3215 * * *$ & $0.0089 * *$ \\
\hline $\operatorname{Lag}(\ln B L T)$ & & $0.6614 * * *$ & \\
\hline Lag (LnASEAN*InBLT) & & $0.2311 * * *$ & \\
\hline
\end{tabular}

These results are in line with Sandberg, Seale Jr, and Taylor (2006) and Thede and Gustafson (2012). Because all the variables were logged, the assumption was that the degree of the elasticity was unit less. However, the panel data used for these study is unbalanced due to missing datas especially fromASEAN countries Export,GDP per capita and GDP were incomplete; thus, applying second generation panel test tests to unbalanced panel data can create computational problems such as the Westerlund error-correction-based panel cointegration tests. Furthermore, we could not employ cross sectional dependency test and others; thus we stick to the first generation panel unit root testing and cointegration which was in line with Hondroyiannis (2006). In summary, regardless of whether there is cross sectional dependency or otherwise, we rely on the assumption of Phillips and Moon (1999) that there is independence in the errors across cross-sections using dynamic models.

\section{Conclusion}

The main purpose of the study is to answer the research question how the nexus among the free trade, institutional quality and economic growth effect the trade from ASEAN countries the exports become uncompetitive because of such hidden tax and high production costs in ASEAN. It can be said that importer/importers can achieve competitive advantage by being involve in corrupt activities as compared to others who are not willing to give bribes. There is less influence of reduction of the tariff, which is based on the potential of intra region. It was discovered that the intra-regional trade reflects a small part of trade including the production. The influence of regional integration and FDI has been shown using a sample of 5 countries. It was found that trade is enhanced through FDI and regional trade. Several connecting relations between trade and FDI exist. A better productivity outcome, quality, and low prices can be achieved by high incorporation of market. FDI investments will be attracted with bigger incorporation of the market that suggests the positive outcome in long run.

The trade can be enhanced or hindered through corruption based on the willingness of firms in the exporting countries to offer bribes at a competitive level. Precisely, the focus of the discussion is on the channels through which global trade can be influenced. This shows that the main influence of corruption, which is an institutional quality on the global trade, is an issue to be empirically investigated. Considering this notion, the previous knowledge has been extended by including some other variables of institutional quality such as good governance, instability of governance and corruption by keeping the focus on flow of trade in ASEAN. Moreover, the data is allowed to decide whether the variables of institutional quality i.e. instability of government, corruption and good governance influence the trade across the border in a positive or negative way in the ASEAN countries. The findings of the study have provided support to the hypothesized results. These results are in line with Sandberg, Seale Jr, and Taylor (2006) and Thede and Gustafson (2012). Because all the variables were logged, the assumption was that the degree of the elasticity was unit less. However, the panel data used for these study is 


\section{ENTREPRENEURSHIP AND SUSTAINABILITY ISSUES}

ISSN 2345-0282 (online) http://jssidoi.org/jesi/

2020 Volume 7 Number 3 (March)

http://doi.org/10.9770/jesi.2020.7.3(42)

unbalanced due to missing datas especially fromASEAN countries Export,GDP per capita and GDP were incomplete; thus, applying second generation panel test tests to unbalanced panel data can create computational problems such as the Westerlund error-correction-based panel cointegration tests. Furthermore, we could not employ cross sectional dependency test and others; thus we stick to the first generation panel unit root testing and cointegration which was in line with Hondroyiannis (2006).

\section{References}

Anderson, J. E., \& Van Wincoop, E. (2003). Gravity with gravitas: a solution to the border puzzle. American Economic Review, 93(1), 170192. https://doi.org/10.1257/000282803321455214

Andersson, J., \& Sundqvist, L. (2018). The effects of the EU-Mexico Free Trade Agreement on trade flows. urn:nbn:se:sh:diva-37556

Athukorala, P.-c. (2012). Asian trade flows: Trends, patterns and prospects. Japan and the World Economy, 24(2), 150-162. https://doi.org/10.1016/j.japwor.2012.01.003

Bergstrand, J. H., Egger, P., \& Larch, M. (2016). Economic determinants of the timing of preferential trade agreement formations and enlargements. Economic Inquiry, 54(1), 315-341. https://doi.org/10.1111/ecin.12241

Boianovsky, M. (2019a). The development economist as historian of economics: The case of William J. Barber. Journal of the History of Economic Thought. https://doi.org/10.1017/S1053837219000178

Boianovsky, M. (2019b). Reacting to Samuelson: Early development economics and the factor-price equalization theorem. https://dx.doi.org/10.2139/ssrn.3417124

Chaney, T. (2008). Distorted gravity: the intensive and extensive margins of international trade. American Economic Review, 98(4), 17071721.https://doi.org/10.1257/aer.98.4.1707

Della Porta, D. (2017). Corrupt exchanges: Actors, resources, and mechanisms of political corruption: Routledge. $\underline{\text { https://doi.org/10.4324/9781315080284 }}$

Doan, T. N., \& Xing, Y. (2018). Trade efficiency, free trade agreements and rules of origin. Journal of Asian Economics, 55, 33-41. https://doi.org/10.1016/j.asieco.2017.12.007

Enders, J. (2004). Higher education, internationalisation, and the nation-state: Recent developments and challenges to governance theory. Higher education, 47(3), 361-382. http://dx.doi.org/10.1023/B:HIGH.0000016461.98676.30

Engle, R. F., \& Granger, C. W. (1987). Co-integration and error correction: representation, estimation, and testing. Econometrica: journal of the Econometric Society, 251-276. http://dx.doi.org/10.2307/1913236

Glick, R., \& Rose, A. K. (2016). Currency unions and trade: A post-EMU reassessment. European Economic Review, 87, 78-91. http://dx.doi.org/10.1016/j.euroecorev.2016.03.010

Hondroyiannis, G. (2006). Private saving determinants in European countries: A panel cointegration approach. The Social Science Journal, 43(4), 553-569. http://dx.doi.org/1016/j.soscij.2006.08.004

Hussain, H.I., Grabara, J., Razimi, M.S.A., \& Sharif, S.P. (2019) Sustainability of Leverage Levels in Response to Shocks in Equity Prices: Islamic Finance as a Socially Responsible Investment, Sustainability, 11 (12), 3260. https://doi.org/10.3390/su11123260

Johansen, S., \& Juselius, K. (1990). Maximum likelihood estimation and inference on cointegration-with applications to the demand for money. Oxford Bulletin of Economics and statistics, 52(2), 169-210. https://doi.org/10.1111/j.1468-0084.1990.mp52002003.x 


\section{ENTREPRENEURSHIP AND SUSTAINABILITY ISSUES}

ISSN 2345-0282 (online) http://jssidoi.org/jesi/

2020 Volume 7 Number 3 (March)

http://doi.org/10.9770/jesi.2020.7.3(42)

Karemera, D., Whitesides, L., \& Smalls, G. (2017). The Impacts Of Regional Free Trade Agreements And Exchange Rate Volatility On World Vegetable And Fruit Trade Flows. International Journal of Food and Agricultural Economics (IJFAEC), 5(1128-2018-058), 25-39. https://doi.org/10.22004/ag.econ.266461

Kölbl, U. (2015). Ein Real-Business-Cycle-Modell mit Komplementarität von Haushalts-und Geschäftskapital für Deutschland und das Vereinigte Königreich.

Krugman, P. R. (1979). Increasing returns, monopolistic competition, and international trade. Journal of international Economics, 9(4), 469-479. https://doi.org/10.1016/0022-1996(79)90017-5

Linder, S. B. (1961). An essay on trade and transformation: Almqvist \& Wiksell Stockholm. https://doi.org/10.2307/2229277

Lu, S. (2017). Why is the Utilization of US Free Trade Agreements Falling for Apparel Imports? https://lib.dr.iastate.edu/itaa_proceedings

Murphy, J. P., \& McLarney, C. (2018). Regionalism and the Multilateral Trading System: The Role of Regional Trade Agreements Geopolitics and Strategic Management in the Global Economy (pp. 1-18): IGI Global. https://doi.org/10.4018/978-1-5225-2673-5.ch001

Nguyen, Q., \& Kim, T. H. (2019). Promoting adoption of management practices from the outside: Insights from a randomized field experiment. Journal of Operations Management, 65(1), 48-61. https://doi.org/10.1016/j.jom.2018.11.001

Ojide, M., Chigozie, A., \& Eke, F. A. (2016). Foreign Direct Investment in Nigeria: Reassessing the Role of Market Size. International Journal of Academic Research in Business and Social Sciences, 6(2), 95-104. https://doi.org/10.6007/IJARBSS/v6-i2/2014

Öncel, A., \& Lubis, R. F. (2017). What impact has free trade area on economies of ASEAN-5 countries? Theoretical \& Appl ied Economics, 24(3). https://econpapers.repec.org/RePEc:agr:journl:v:3(612):y:2017:i:3(612):p:51-62

Park, I., \& Park, S. (2016). Trade facilitation provisions in regional trade agreements: discriminatory or non-discriminatory? East Asian Economic Review, 20(4), 447-467. https://dx.doi.org/10.2139/ssrn.2894094

Pearson, A. (2017). Why Don't African Countries Trade More With Each Other? The Role of Border Crossings in General Equilibrium. Phillips, P. C., \& Moon, H. R. (1999). Linear regression limit theory for nonstationary panel data. Econometrica, 67(5), 1057-1111. https://doi.org/10.1111/1468-0262.00070

Rahmouni, O., \& Debbiche, I. (2017). Effects of the Euro-Mediterranean Partnership on Tunisian FDI Inflows. The International Trade Journal, 31(4), 386-397. https://doi.org/10.1080/08853908.2017.1331771

Rajapakse, C. R. (2019). Stock Market Performance, Exchange Rate Volatility and Foreign Direct Investment to Sri Lanka. Asia Proceedings of Social Sciences, 4(3), 20-22. https://doi.org/10.31580/apss.v4i3.817

Salim, A., Razavi, M. R., \& Afshari-Mofrad, M. (2017). Foreign direct investment and

technology spillover in Iran: The role of technological capabilities of subsidiaries. Technological Forecasting and Social Change, 122, 207-214. https://doi.org/10.1016/j.techfore.2015.09.012

Sandberg, H. M., Seale Jr, J. L., \& Taylor, T. G. (2006). History, regionalism, and CARICOM trade: A gravity model analysis. The Journal of Development Studies, 42(5), 795-811. https://doi.org/10.1080/00220380600741995

Sartor, M. A., \& Beamish, P. W. (2018). Host market government corruption and the equity-based foreign entry strategies of multinational enterprises. Journal of International Business Studies, 49(3), 346-370. https://doi.org/10.1057/s41267-017-0115-7.

Schweighofer-Kodritsch, S. (2018). Time preferences and bargaining. Econometrica, 86(1), 173-217. https://doi.org/10.3982/ECTA14396 Shiny, S. Y., \& McKenzie, J. (2016). Asymmetric Cultural Discounting and Pattern of Trade in Cultural Products: Empirical Evidence in Motion Pictures. The World Economy. https://doi.org/10.1111/twec.12861

Sousa, J. (2012). The currency union effect on trade is decreasing over time. Economics Letters, 117(3), 917-920. https://doi.org/10.1016/j.econlet.2012.07.009

Thede, S., \& Gustafson, N. Å. (2012). The multifaceted impact of corruption on international trade. The World Economy, 35(5), 651-666. https://doi.org/10.1111/j.1467-9701.2012.01436.x

Thompson, G. F. (2017). Are There Any Limits to 'Globalisation'? International Trade, Capital Flows and Borders 1 The Caribbean Economies in an Era of Free Trade (pp. 23-46): Routledge. https://doi.org/10.4324/9781351147521-2 


\section{ENTREPRENEURSHIP AND SUSTAINABILITY ISSUES}

ISSN 2345-0282 (online) http://jssidoi.org/jesi/

2020 Volume 7 Number 3 (March)

http://doi.org/10.9770/jesi.2020.7.3(42)

Velde, D. W., Page, S., \& Morrissey, O. (2017). Regional integration, trade, foreign direct investment and migration Regional Integration and Poverty (pp. 27-60): Routledge. http://www.odi.org.uk/iedg/Projects/ec_prep1.pdf

Wilson, M. K., \& Bala, A. P. (2019). Regional Integration and Cross-Border Mergers and Acquisitions in Africa. Journal of Economic Integration, 34(1), 109-132. http://dx.doi.org/10.11130/jei.2019.34.1.109

Paitoon CHETTHAMRONGCHAI is a lecturer of Department of Marketing, Kasetsart Business School, Thailand. He holds Ph.D. in Marketing Management from the University of Manchester, England. His areas of expertise are Marketing Management and Modern Management.

ORCID: https://orcid.org/0000-0002-9744-4358

Kittisak JERMSITTIPARSERT holds Ph.D. in Social Sciences from Kasetsart University, Thailand. He is currently a researcher at Chulalongkorn University Social Research Institute, a part-time researcher at Ton Duc Thang University, and the secretary general of Political Science Association of Kasetsart University. His areas of expertise are Political Science, Public and Business Administration, and Interdisciplinary Research in Social Sciences.

ORCID: https://orcid.org/0000-0003-3245-8705

Sakapas SAENGCHAI is studying Ph.D. in Public Administration at Ramkhamhaeng University Thailand. He currently is Assistant Professor in Public Administration at the Faculty of Humanities and Social Sciences, Suan Sunandha Rajabhat University. His areas of expertise are Public and Private Administration and Interdisciplinary Studies in Social Sciences.

ORCID: $\underline{\text { https://orcid.org/0000-0003-0883-1119 }}$

Register for an ORCID ID:

https://orcid.org/register

Copyright (C) 2020 by author(s) and VsI Entrepreneurship and Sustainability Center

This work is licensed under the Creative Commons Attribution International License (CC BY).

http://creativecommons.org/licenses/by/4.0/

c) (i) Open Access 